Gut, 1971, 12, 218-221

\title{
A cross-over comparison of the effect of morphine, pethidine, pentazocine, and phenazocine on biliary pressure
}

\author{
G. ECONOMOU AND J. N. WARD-MCQUAID
}

From the Mansfield Group of Hospitals

SUMMARY The effects on biliary pressure of pentazocine, morphine, pethidine, and phenazocine were compared by direct measurement through a ' $T$ ' tube after choledochotomy. In two withinpatient comparisons, the mean increases in biliary pressure following intramuscular morphine were significantly greater than those following pentazocine. When pethidine and phenazocine were compared with pentazocine, the mean increases were lower following pentazocine but not to a statistically significant extent. Pentazocine appears to be the most appropriate strong analgesic in biliary and pancreatic disease.

Morphine and pethidine are perhaps the two drugs most commonly used for pain of biliary and pancreatic origin, but both produce a marked rise in biliary pressure. The effect of morphine is about twice that of pethidine (Jacobsson, 1957; Efron, 1958; Kjellgren and Löf, 1959; Kjellgren, 1960; Hopton and Torrance, 1967). Hopton and Torrance (1967) advocated the use of phenazocine (Narphen), the first benzomorphan derivative used extensively for pain, as it produced only a minimal rise in biliary pressure.

We have used the newer benzomorphan derivative pentazocine (Fortral) extensively for pain relief (Conaghan, Jacobsen, Rae, and WardMcQuaid, 1966; Ward-McQuaid, 1969; Economou, Monson, and Ward-McQuaid, 1971) and have found it to be efficient and with few side effects. The object of the present cross-over trial was to compare the effects on biliary pressure of pentazocine with that of morphine, pethidine, and phenazocine. A simple direct manometric method was used. No previous such controlled study on the effect of pentazocine on the biliary pressure could be found in the literature.

\section{Method}

Measurements of bile pressure were made after operation through the ' $T$ ' tube draining the common bile duct after cholecystectomy and choledochotomy. In the 31 patients studied, cholangiography had been normal after exploration of the duct. A small sound had been passed into the duodenum Received for publication 9 December 1970. through the sphincter at operation, but a formal sphincterotomy had not been performed on any patient. Bile pressure was measured directly in centimetres of bile through a transparent plastic tube attached to the shortened $12 \mathrm{~F}$ ' $\mathrm{T}$ ' tube.

The trial was of cross-over design and the patients willingly cooperated. In each patient the resting pressure was measured, the patient lying flat with one pillow. There was a variation of up to $1.5 \mathrm{~cm}$ on respiration; the mean was taken. The bile pressure, sometimes raised after operation, had settled in all patients, at least to less than $18 \mathrm{~cm}$ of bile above the duct. The distance from the duct to the skin at the anterior abdominal wall had been measured at operation, and this was used as a base line for postoperative measurements. Each patient received the two drugs given intramuscularly on consecutive days, the order of administration being randomized. The effect on bile pressure was measured 30, 60, and 120 minutes after the injection.

Two groups of patients were studied two to four days after operation. One group of 11 patients received 30-45 $\mathrm{mg}$ pentazocine and 10-15 $\mathrm{mg}$ morphine (group 1) and the other group of 11 patients received $30-45 \mathrm{mg}$ pentazocine and 75$100 \mathrm{mg}$ pethidine (group 2).

A further two groups of patients were studied eight to ten days after operation. One group of 10 patients received $30-45 \mathrm{mg}$ pentazocine and 10-15 mg morphine (group 3) and a second group of 10 patients received 30-45 $\mathrm{mg}$ pentazocine and 2-3 mg phenazocine (group 4). Several of the patients were studied both at two to four days and eight to ten days after operation. 


\section{Results}

\section{GROUP 1}

In this group of 11 patients, the mean dose was $31.4 \mathrm{mg}$ of pentazocine and $10.5 \mathrm{mg}$ of morphine. The mean number of days after operation when the injections were given was $3 \cdot 1$ for pentazocine and $3 \cdot 2$ for morphine.

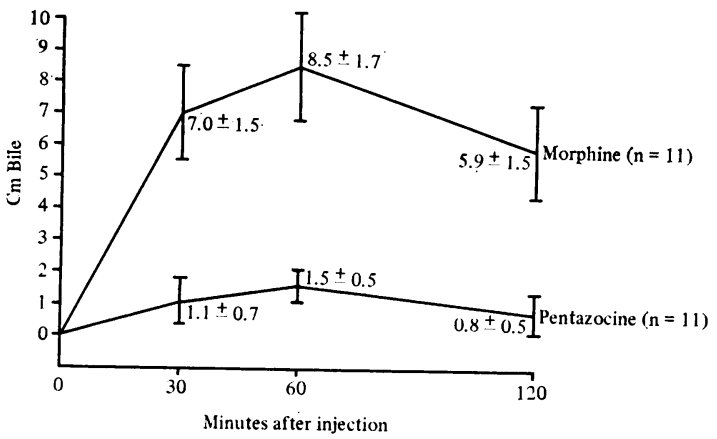

Fig. 1 Changes in biliary pressure after pentazocine and morphine (means + or - standard error).

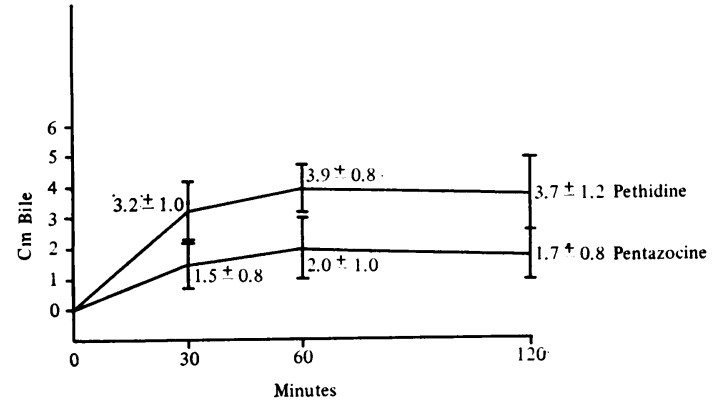

Fig. 2 Changes in biliary pressure after pentazocine and pethidine (means + or - standard error).

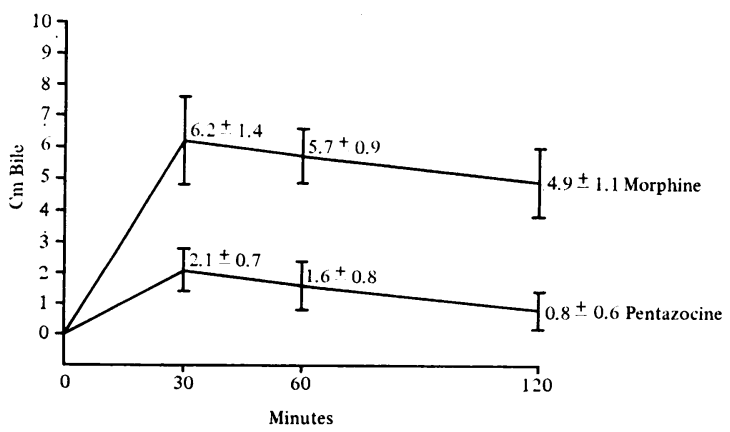

Fig. 3 Changes in biliary pressure after pentazocine and morphine (means + or - standard error.)
The mean changes in biliary pressure are shown in Figure 1. In the pentazocine group, only the mean increase of $1.5 \mathrm{~cm}$ of bile 60 minutes after injection is statistically significant $(P<0.02)$. In the morphine group, the mean increase of $7 \mathrm{~cm} 30$ minutes after injection, and the maximum mean increase of $8.4 \mathrm{~cm}$ at 60 minutes, are both statistically highly significant $(\mathrm{P}<0.001)$, and the mean increase at 120 minutes is also statistically significant $(P<0.01)$. The differences between the effects of pentazocine and morphine at 30 minutes and 120 minutes are both statistically significant at the $1 \%$ level while the difference at 60 minutes is significant at the $0.2 \%$ level.

\section{GROUP 2}

In this group also of 11 patients the mean dose of pentazocine was $36.6 \mathrm{mg}$ and that of pethidine $89.5 \mathrm{mg}$. The mean number of days after operation when the injections were given was $2 \cdot 8$ for pentazocine and 2.7 for pethidine.

The mean increases in this group were both maximal at 60 minutes, $2.0 \mathrm{~cm}$ for pentazocine and $3.9 \mathrm{~cm}$ for pethidine (Fig. 2). None of the mean increases for pentazocine is statistically significant. In the pethidine group all the mean increases are statistically significant; at $30 \mathrm{~min} P<0.01$, at $60 \mathrm{~min}$ $P<0.001$, and at 120 min $P<0.02$. The difference between the effects of pentazocine and pethidine is not statistically significant at any time after the injections.

\section{GROUP 3}

In this group of 10 patients the mean dose of pentazocine was $35.4 \mathrm{mg}$ and $12.3 \mathrm{mg}$ of morphine. The mean interval between operation and injection was 9.1 days for pentazocine and 9.7 days for morphine. The mean changes in biliary pressure are shown in Figure 3. In the pentazocine group, only the mean increase of $2.1 \mathrm{~cm}$ bile at $30 \mathrm{~min}$ is statistically significant $(P<0.02)$. In the morphine group all the mean increases are statistically significant; $6.2 \mathrm{~cm}$ at $30 \mathrm{~min}$ and $4.9 \mathrm{~cm}$ at $120 \mathrm{~min}$ $(\mathrm{P}<0.002)$ and $5.7 \mathrm{~cm}$ at $60 \mathrm{~min}(\mathrm{P}<0.001)$. The differences between the effects of pentazocine and morphine at 30,60, and 120 min are statistically significant, at $5 \%, 1 \%$, and $2 \%$ levels respectively.

\section{GROUP 4}

There were 10 patients in this group and the mean doses were $34.5 \mathrm{mg}$ of pentazocine and $2.3 \mathrm{mg}$ of phenazocine. The mean number of days after operation was 8.5 for pentazocine and 9.2 for phenazocine.

The mean increase of $2.8 \mathrm{~cm}$ of bile with pentazocine $30 \mathrm{~min}$ after injection (Fig. 4) is the 
highest of all the four pentazocine groups, and is statistically significant $(P<0.01)$. The mean phenazocine rise at $30 \mathrm{~min}$ was $3.8 \mathrm{~cm}$ of bile. Two patients had relatively large increases following injection of the two drugs. None of the differences between the effects of pentazocine and phenazocine is statistically significant.

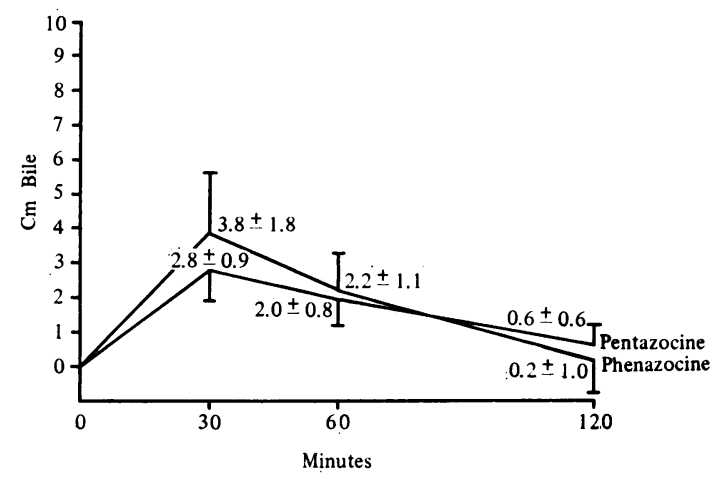

Fig. 4 Changes in biliary pressure after pentazocine and phenazocine (means + or - standard error).

\section{Discussion and Conclusion}

Various techniques have been used to assess biliary pressure and the tone of the biliary sphincter. We used the simplest method of direct measurement without recording devices (Kjellgren and Löf, 1959; Boulter, 1961; Hopton and Torrance, 1967). Electromanometry by transducers (Jacobsson, 1957; Kjellgren and Löf, 1959; Marth, 1968) and methods involving transit times (Boulter, 1961; Daniel, 1965; Daniel and Singh, 1969) have also been advocated. Indirect methods have also been used, often combined with direct measurements, by radiography (Boulter, 1961; Daniel, 1965) and by estimations of serum amylase or lipase (Danhof, 1966; Hinshaw, Hobler, Borja, and Sahler, 1966).

It is well known that bile pressure varies in the same individual from day to day, with the widest variation in the early days after operation. A week after operation, however, these variations are less marked (Jacobsson, 1957). Hopton and Torrance (1967) did not consider variations of $2 \mathrm{~cm}$ of great significance.

The unsophisticated method used in this study gave reasonably consistent results. This is particularly illustrated by the small scatter of results in the four groups receiving pentazocine.

When our results with morphine are compared with others in the literature, the rise seems somewhat slower with a lower peak than that obtained by intramuscular injection (Kjellgren, 1960; Hopton and Torrance, 1967) and as could be expected by intravenous injection (Efron, 1958; Boulter, 1961). Our maximum rise occurred at $\mathbf{3 0}$ minutes nine days after operation, compared with 10-30 minutes, while three days after operation the rise was maximal at 60 minutes. We confirmed the proportionate increase in pressure after morphine and pethidine (Jacobsson, 1957; Efron, 1958; Hopton and Torrance, 1967) but the maximum rise with pethidine, as with morphine, occurred earlier than in our patients. All our patients, however, were examined three days after operation. Kjellgren and Löf (1959) had lower and slower rises with both morphine and pethidine in similar dosage when given by subcutaneous injection (Kjellgren and Löf, 1959).

The usual specific gravity of bile duct bile is approximately $1 \cdot 1$, so our results could be $10 \%$ higher in $\mathrm{cm}$ water.

The mean rise at one hour after injection of pethidine three days after operation was almost twice that of pentazocine $(3 \cdot 9: 2 \cdot 0 \mathrm{~cm})$. This is not statistically significant, but further data from a short unpublished study recently carried out at this hospital on the effect of intravenous pentazocine and pethidine in the anaesthetized patient supports the suggestion that pentazocine has a smaller effect on biliary pressure than pethidine.

After a premedication of only atropine and a sedative, the bile pressure was measured by the umbilical catheter used for operative cholangiography. This had been introduced into the common bile duct through the cystic duct. The maximum rise in pressure at 15 minutes after intravenous injection was followed by a fall to resting pressure after injection of the dye for cholangiography. In 16 patients who received a mean dose of $30.9 \mathrm{mg}$ pentazocine the mean increase in bile pressure at $15 \mathrm{~min}$ was $1.5 \mathrm{~cm}$, a rise statistically significant at the $5 \%$ level. In eight patients given a mean of $87.5 \mathrm{mg}$ pethidine the rise in pressure was $3 \mathrm{~cm}$ at $15 \mathrm{~min}$, a rise significant at the $0.1 \%$ level. The difference between the effects of the two drugs is not statistically significant.

Our results with phenazocine nine days after operation showed a slight but definite rise and confirmed the work of Hopton and Torrance (1967). This rise was less than that with pethidine three days after operation. In both the phenazocine and pentazocine groups nine days after operation the same two patients had a large rise, so that the mean rise for phenazocine was $3.8 \mathrm{~cm}$ and pentazocine $2.8 \mathrm{~cm}$. This pentazocine figure was the highest rise in the four pentazocine groups.

Our results show that pentazocine caused only a 
minimal rise of biliary pressure in 42 estimations in 31 patients in this controlled study. The maximum mean increases one hour after injection three days after operation were $1.5 \mathrm{~cm}$ and $2.0 \mathrm{~cm}$, while $30 \mathrm{~min}$ after injection nine days after operation the maximum mean increases were $2 \cdot 0$ and $2 \cdot 8 \mathrm{~cm}$.

There are three references in the literature to the effect of pentazocine on biliary pressure.

Hinshaw et al (1966) cited only three patients with ' $T$ ' tube drainage of the common bile duct in whom intramuscular pentazocine produced spasm of the sphincter of Oddi within 40 minutes. There was no rise in the serum amylase in these patients, and no further details were given. They concluded, however, apparently on this meagre evidence, that 'pentazocine produces a spasm of the sphincter of Oddi just as do the narcotics'.

Danhof (1967) found no elevation in serum amylase signifying spasm of the sphincter of Oddi after $15 \mathrm{mg}$ and $30 \mathrm{mg}$ doses of pentazocine. However, two of the five subjects receiving $40 \mathrm{mg}$ pentazocine had serum amylase levels above the upper limit of normal.

Duran and Landa (1967) estimated the pressure necessary to pass contrast medium through the sphincter of Oddi in 30 patients with a ' $T$ ' tube after choledochotomy. They concluded that there was no difference between pentazocine and control studies since both required a pressure of 15-17 $\mathrm{cm}$ water to overcome sphincter resistance. Pethidine required $34-38 \mathrm{~cm}$ and morphine $39-48 \mathrm{~cm}$. These results confirm that morphine causes a greater spasm of the sphincter of Oddi than does pethidine. They concluded that pentazocine had no effect on the sphincter, and therefore can be used to treat pain due to biliary and pancreatic disease.

Morphine by itself has long been used as an analgesic for biliary and pancreatic pain, often combined with atropine or with an antispasmodic such as propantheline bromide (Pro-Banthine) (Boulter, 1961). We have found, however, that propantheline bromide does not always enable dye to pass readily into the duodenum soon after exploration of the sphincter of Oddi, when the biliary pressure is often raised.

Pethidine has also been widely used, sometimes combined with levallorphan tartrate (Pethilorfan). This combination had less effect on biliary pressure than did pethidine alone (Kjellgren and Löf, 1959).

Hopton and Torrance (1967) reviewed the more recent analgesics, including dextromoramide (Palfium) and levorphanol (Dromoran), which both produced a marked (over $10 \mathrm{~cm}$ ) or moderate (over $5 \mathrm{~cm}$ ) rise of biliary pressure after doses adequate to give useful analgesia. Phenoperidine (Operidine) caused at most a minimal rise. It is however, short acting, and of most value just before or during anaesthesia.

It would seem that pentazocine is the most appropriate analgesic available at present in pain from biliary and pancreatic disease or in operations for its relief. It is an effective analgesic, causing only a minimal rise of biliary pressure and minimal side effects, while it is at the same time of low dependence liability (World Health Organization, 1966, 1969, and 1970) and free from the restrictions of the British Dangerous Drugs Act. Nevertheless, it seems reasonable to add propantheline bromide, at least in acute cases, to counteract any possible spasm of the sphincter.

We are grateful to our patients and colleagues for their willing help, and to $\mathrm{Mr}$ M. Palmer of the Winthrop Laboratories, Surbiton, for statistical analysis of the results.

\section{References}

Boulter, P. S. (1961). The effects of analgesics and antispasmodics on the flow through the human common bile duct. Guy's Hosp. Rep., 110, 246-262.

Conaghan, J. P., Jacobsen, M., Rae, L., and Ward-McQuaid, J. N. (1966). Pentazocine and Phenazocine: a double blind comparison of two benzomorphan derivatives in postoperative pain. Brit. J. Anaesth., 38, 345-354.

Danhof, I. E. (1967). Pentazocine effects on gastro-intestinal motor functions in man, Amer. J. Gastroent., 48, 295-310.

Duran, I., and Landa, L. V. (1967). Effecto de la Pentazocina (WIN 20.228) sobre el esfinder de Oddi. Rec. Gastroent. Med., 30, 529-536.

Daniel, O. (1965). A simple method of measuring intra-visceral pressure, of value in ureterocolic anastomosis, and study of pressure and flow in the common bile duct. Irish J. med. Sci. 6, 415-425.

Daniel, O., and Singh, M. L. (1969). Measurement and control of bowel pressure in ureterocolic anastomosis. Brit. J. Urol., 41, 32-39.

Economou, G. C., Monson, R., and Ward-McQuaid, J. N. (1971). Oral pentazocine and phenazocine: a comparison in postoperative pain. Brit. J. Anaesth., in the press.

Efron, G. (1958). Analgesia in pancreatitis with special reference to the effect on pressure in the common bile duct. $S$. Afr. med.J., 32, 1124-1128.

Hinshaw, J. R., Hobler, K. E., Borja, A. R., and Sahler, C. O. (1966). Pentazocine, a potent nonaddicting analgesic. Amer. J. med. Sci., 251, 57-62.

Hopton, D. S., and Torrance, H. B. (1967). Action of various new analgesic drugs on the human common bile duct. Gut, 8, 296-300.

Jacobsson, B. (1957). Determination of pressure in the common bile duct at and after operation. Acta chir. scand., 113, 483-488.

Kjellgren, K., and Löf, B. (1959). Anaesthesia and operative cholangiography. Acta chir. scand., 118, 37-44.

Kjellgren, K. (1960). Persistence of symptoms following biliary surgery. Ann. Surg., 152, 1026-1035.

Marth, W. (1968). Kontinuierliche Elektromanometrie der Gallenwege. Z. ges. exp. Med., 148, 108-114.

Ward-McQuaid, J. N. (1969). Pentazocine in post-operative pain. Clin. Trials J., 6, 129-138.

World Health Organization (1966). WHO Expert Committee on Dependence-Producing Drugs, 15th Report. Wld Hlth Org. techn. Rep. Ser., 343, 6.

World Health Organization (1969). WHO Expert Committee on Drug Dependence, 16th Report. Wld Hlth Org. techn. Rep. Ser., 407, 23.

World Health Organization (1970). WHO Expert Committee on Drug Dependence, 17th Report. Wld Hlth Org. techn. Rep. Ser., 437, 24. 